\title{
O mentecapto de Itaguaí, história, loucura e saber psiquiátrico: diálogos historiográficos em torno de "O alienista" de Machado de Assis
}

\section{The madman of Itaguai, history, madness, and psychiatric knowledge: historiographic dialogues about "The Alienist," by Machado de Assis}

REIS, José Roberto Franco. O mentecapto de Itaguaí, história, loucura e saber psiquiátrico: diálogos historiográficos em torno de "O alienista" de Machado de Assis. História, Ciências, Saúde Manguinhos, Rio de Janeiro, v.23, n.4, out.-dez. 2016, p.1095-1112.

\section{Resumo}

O artigo analisa a obra "O alienista", de Machado de Assis, a partir de um diálogo com a historiografia (nem sempre escrita por historiadores) que, desde o final dos anos 1970 até períodos mais recentes, investiga tanto as práticas de intervenção psiquiátricas vigentes no Brasil da segunda metade do século XIX até o começo do XX quanto os aportes teóricos e as lógicas de poder e sociabilidades que davam sustentação a tais práticas. A perspectiva aqui assumida interpreta "O alienista" como um vigoroso "testemunho histórico", num registro eminentemente crítico, dos momentos iniciais de implantação da medicina mental no Brasil e de seu correlato institucional, que é o hospício.

Palavras-chave: história da loucura; saber psiquiátrico; literatura e história; poder e controle social; nascimento do hospício.

\section{Abstract}

From the early 1970s until more recently, historiography (which is not always written by historians) has investigated the psychiatric intervention practices that prevailed in Brazil from the latter half of the nineteenth century through the early twentieth, along with their theoretical foundations and the underlying logics of power and sociability. The article analyzes the novella "The Alienist," by Machado de Assis, by engaging in dialogue with this field. The book is interpreted as a robust and eminently critical "historical witness" of the early emergence of mental health medicine in Brazil and its institutional correlate, the asylum.

Keywords: history of madness; psychiatric knowledge; literature and history; power and social control; birth of the asylum. 


\begin{abstract}
O século XIX bem merece o título de "século dos manicômios". Em nenhum outro século o número de hospitais destinados a alienados foi tão grande. Em nenhum outro século a terapêutica da loucura foi tão vinculada à internação, em nenhum outro século o número de internações atingiu proporções tão grandes; mais ainda, em nenhum outro século a variedade de diagnósticos, para justificar a internação, foi tão ampla
\end{abstract}

(Pessoti, 1986, p.9).

Não é evidentemente motivo de surpresa que a sensibilidade de Machado de Assis tenha captado a perspectiva nova que se apresentava para os destinos da loucura no século XIX e tenha se disposto a enfrentar o tema no conto "O alienista", parte da coletânea Papéis avulsos, editada em 1882. Surpreendente é o teor da crítica machadiana que assume um tom quase profético, antecipando um tipo de debate que só ganharia fôlego quase um século depois, notadamente com a publicação do fascinante História da loucura, de Michel Foucault. ${ }^{1}$ Como sugere Cunha (2003, p.120), em "O alienista" Machado busca demolir "a noção 'científica' de verdade para, com a sagacidade que o caracteriza, produzir páginas de fina ironia e 'brilhante antecipação histórica'" (destaque meu).

Com efeito, o que se discute desde já em "O alienista" não é apenas o tema da loucura em si e do saber que se constrói em torno dela, mas sobretudo a questão das relações entre saber e poder. O poder que Simão Bacamarte - personagem que na clave irônica de Machado é definido como o "maior dos médicos do Brasil, de Portugal e das Espanhas" - adquire de, brandindo a espada da ciência, demarcar os limites definitivos da razão e da loucura e a partir disso determinar quem poderia circular livremente pelas ruas da pacata Itaguaí. Particularmente nesse caso o que a fina ironia do autor parece querer atingir é a fragilidade dos pressupostos dessa ciência que pretende cuidar da "patologia cerebral", seus critérios fluidos e imprecisos, e mesmo assim outorgar-se o direito de apontar quem é quem no universo à deriva, flutuante, da loucura e, de posse dessa compreensão, encerrar todos os ditos loucos em um mesmo espaço institucional. Onde antes imperava a convivência entre "loucos" e "não loucos", ainda que oscilando entre a aceitação e a rejeição da loucura, ${ }^{2}$ passa a haver necessariamente periculosidade. ${ }^{3}$ Em vista disso, Itaguaí, que, "entre outros pecados ... tinha o de não fazer caso dos dementes", adotando o "ruim costume" de deixar os loucos furiosos aos cuidados da própria família em casa e os mansos à solta pelas ruas, após a criação da Casa Verde - nome dado ao asilo "por alusão à cor das janelas" -, se vê sacudida por uma "torrente de loucos" (Assis, 1997, p.40-42).

Sendo assim, neste breve texto, pretendemos refletir sobre a crítica que Machado empreende na obra "O alienista" às ambições de poder da psiquiatria e a insuficiências e limites de seus pressupostos científicos, interpretando-a, em diálogo com a historiografia que tratou do tema, como um vigoroso "testemunho histórico" dos momentos iniciais de instalação da medicina mental no Brasil e de seu correlato institucional, que é o hospício. Sem maiores digressões teóricas sobre o estatuto da obra ficcional, a perspectiva de análise aqui assumida se identifica com a proposta dos historiadores Chalhoub e Pereira (1998, p.7-13), ao tratar a literatura como "evidência histórica objetivamente determinada" - vale 
dizer, como "testemunho histórico" de uma experiência social particular. Nesse sentido, se submete, tal como qualquer outra evidência, às "interrogações sistemáticas" próprias ao ofício do historiador quando aborda suas fontes, sejam elas literárias ou não, inserindo-as "no movimento da sociedade" e investigando "as suas redes de interlocução social", de modo a capturar a "lógica social do texto".

\section{O bacamarte machadiano e o nascimento da psiquiatra: literatura, história e historiografia}

Principio, então, por indicar os inúmeros paralelos que se podem estabelecer entre a novela e o cenário brasileiro do período em que ela foi publicada, 1882, apesar do que é dito por seu narrador: que a história se passa em vagos "tempos remotos", algo em torno de 1789 e $1808 .{ }^{4}$ Primeiro, a surpresa que a "ideia de meter os loucos na mesma casa vivendo em comum" causa em toda a vila, encontrando "grande resistência": "Quem é que viu agora meter todos os doidos dentro da mesma casa?" sentenciava um vereador, indignado com a proposta que lhe soou absurda a alguns até parecendo "em si mesma sintoma de demência" (Assis, 1997, p.40-41). Tal procedimento, que, à primeira vista, selava o compromisso da medicina alienista com a caridade cristã, embora esta última entrasse apenas como "tempero, como o sal das coisas" e nunca como objetivo principal, deixava entrever, na intimidade da conversa amistosa, seu sentido verdadeiro: "Estudar profundamente a loucura, os seus diversos graus, classificar-lhe os casos, descobrir enfim a causa do fenômeno e o remédio universal" (Assis, 1997, p.42). Portanto, seu ponto de partida é a criação de um espaço possível de produção de saber e de experimentação de uma terapêutica visando à cura, ou seja, de um lugar imprescindível à ciência de reunião da teoria e da prática. Com efeito, uma das principais lutas empreendidas pelos alienistas brasileiros na segunda metade do século XIX era justamente pela criação de hospícios como lugares específicos de reclusão da insanidade, sob exclusivo controle médico. ${ }^{5}$ Ocorre que, se num primeiro momento foi possível a instituição de tais lugares - o Hospício Pedro II no Rio de Janeiro foi criado por lei do Império em 1841, mas inaugurado em 1852, e o Asilo Provisório de Alienados de São Paulo, por lei municipal de 1848, mas também inaugurado em 1852 - sua transformação em espaço exclusivo de competência médica, e de uma medicina especial devotada ao comportamento, vai envolver um acurado debate, no caso do Rio de Janeiro, com a administração leiga da Santa Casa da Misericórdia (Machado et al., 1978; Teixeira, 1998). ${ }^{6}$ Aqui, o que se vislumbra é o mesmo que Simão Bacamarte, num rasgo íntimo, desvenda como "o mistério do seu coração": possibilitar o estudo científico da loucura, sua identificação e cura. ${ }^{7}$ Outro aspecto que ressalta no conto é a descrição que faz dos inúmeros personagens que passam a compor a "torrente de loucos" que invadem a Casa Verde. Oradores que fazem discursos "ornados de tropas, de antíteses, de apóstrofes, com seus recamos de grego e latim"; loucos por amor como Falcão, de 25 anos, que, julgando-se "a estrela d'alva, abria os braços e alargava as pernas, para dar-lhes certa feição de raios", ficando horas nessa posição; os com mania de grandeza, como o escrivão que era mordomo do rei e o boiadeiro a "distribuir boiadas a toda gente"; havia também os episódios de monomania religiosa, caso de João de Deus, cuja loucura era prometer o "reino dos céus a quem o adorasse, e as penas do inferno aos outros", além do licenciado Garcia, que permanecia mudo, imaginando que 
no dia em que proferisse uma só palavra "todas as estrelas se despegariam do céu e abrasariam a terra", recebendo tal poder de Deus (Assis, 1997, p.43-44).

Interessante observar a semelhança dessas descrições com a galeria de tipos de rua que circulavam pela cidade do Rio de Janeiro no mesmo período, elencada por cronistas como Mello Morais Filho e outros (Cunha, 1990; Engel, 2001). Príncipe Obá, Tomaz Cachaça, Miguelista, Forte Lida, Príncipe Natureza, Capitão Nabuco, Maria Doida, Castro Urso, Policarpo, Padre Quelé, Adalberto, o filósofo do Cais, Maria da Praia Grande e até um certo Chico das Cambraias, "folgazão emérito" , cantor de lundus e modinhas residente com mulher e filhos na rua do Hospício, cujo "nome e ... características de personalidade" coincidem com o "encerrado arbitrariamente na Casa Verde" em decorrência da volúpia científica do médico Simão Bacamarte (Cunha, 1990, p.19; Engel, 2001, p.21-53). ${ }^{8}$

Tais personagens, conforme salienta Magali Engel (2001, p.23-24), "presentes nas ruas movimentadas, nos arrabaldes, nos estabelecimentos públicos, nas igrejas", por mais "estranhos e diferentes que fossem considerados seus hábitos", despertavam o "riso, a compaixão, as injúrias grosseiras e a troça, às vezes cruel ... sentimentos mistos e contraditórios que, oscilando entre a aceitação e a rejeição, demonstra[vam] de qualquer forma a existência de um espaço de convivência entre o louco e o não louco". A existência de tais espaços de convivência, de incorporação ao dia a dia da cidade, significava que os loucos, pelo menos enquanto não apresentassem comportamentos identificados como perigosos, conseguiam manter um "certo saber e um certo poder sobre si mesmos e sobre a sua loucura", respondendo tanto pela sua sobrevivência quanto "muitas vezes, garantindo a subsistência de suas famílias" (Engel, 2001, p.49). Ao habitante do Rio de Janeiro na época, provavelmente, a notícia do enclausuramento de algumas dessas figuras pitorescas no Hospício Pedro II pode ter causado, pelo menos no início, a mesma perplexidade que provocou na população de Itaguaí a internação de certos personagens presentes no seu cotidiano, como foi o caso de um tal Costa, cidadão "dos mais estimados" da província:

Impossível!

- Qual impossível! foi recolhido hoje de manhã.

- Mas, na verdade, ele não merecia... Ainda em cima! depois de tanto que ele fez...

(Assis, 1997, p.51)

De modo idêntico, a informação do recolhimento de sua prima, "senhora perfeitamente ajuizada", cujo único crime teria sido o de "interceder por um infeliz", lança o "terror à alma da população" (Assis, 1997, p.53). De fato, tal atitude provoca tamanha estranheza, que a imaginação popular só consegue enxergar no episódio motivos pessoais, picuinhas até amorosas: "Comentava-se o caso nas esquinas, nos banheiros; edificou-se um romance, umas finezas namoradas que o alienista outrora dirigira à prima do Costa, a indignação do Costa e o desprezo da prima. E daí a vingança. Era claro (Assis, 1997, p.53)".

Outro aspecto a ressaltar diz respeito à presença de certa percepção popular, leiga, do que era ser (ou estar) louco, cuja revelação se dava à população por meio de uma série de sinais, visíveis a olho nu, como "vestiário exótico, hábitos estranhos, atitudes diferentes, gestos e palavras 'incompreensíveis', alterações na fisionomia" (Engel, 2001, p.24), ou na forma "por 
excelência da loucura que era o delírio" (Cunha, 1986, p.78). As concepções científicas da loucura, sobretudo nesse primeiro momento, podem ter-se, em alguma medida, apoiado em muitas dessas visões leigas, num processo de circularidade cultural, de partilhamento de práticas culturais, em que o saber popular é transformado e enquadrado em alguma classificação médica (Engel, 2001). Resta que essa apropriação não se dá, a meu ver, pela valorização da proximidade entre ambas, antes opera por meio da desqualificação das crenças e saberes populares que estariam distantes e até em oposição à verdade da ciência. Além disso, a tendência do saber alienista é, no seu processo de especialização, impor à loucura uma espécie de ocultamento, de perda de visibilidade, de forma que só o olhar treinado do psiquiatra teria condições de identificar. Com efeito, foi nos anos 1820 e 1830 que Esquirol, alinenista francês, formulou a teoria da monomania que, de acordo com Reis (1994, p.21), pretendia "esclarecer o paradoxo da convivência num mesmo indivíduo de um comportamento aparentemente racional e 'normal' e atos repentinos e irresistíveis de extrema periculosidade, o principal deles sendo o impulso homicida". Nesse sentido, sugere o autor, tratar-se-ia, doravante, de uma "loucura parcial, sem delírio aparente", ou seja, "sem objetividade imediata, impossível de ser antevista pelo comportamento espetacular do louco" (p.22). E acrescenta:

Nessa percepção, aquilo que inicialmente surgira numa querela exclusiva com o aparelho judiciário, define já uma mudança de atitude da psiquiatria que busca agora combater o risco 'virtual' da loucura, lançando um olhar de suspeição sobre um vasto leque de comportamentos humanos. Aqui, uma outra consequência também: relativiza-se necessariamente o anterior caráter dicotômico da oposição normal-patológico, onde se era louco ou não. Relativização que, em bases muito menos controversas, a teoria da 'degeneração' moreliana de certa forma vem aprofundar mas também aperfeiçoar. Por isso que, para Morel [alienista francês] não se tratava mais do paradoxo de uma loucura parcial, mas apenas a manifestação de um estágio de uma loucura una, integral, garantida na base pelo substrato da degeneração latente e previsível pela presença da hereditariedade mórbida. Por aí, uma variedade de estados intermediários da loucura passam a encontrar ancoradouro seguro, onde, então a figura do limítrofe ou, como diz Cunha, do "'demi-fou', do degenerado a 'caminho' da loucura, do tarado portador de uma doença invisível” torna-se o objeto central de preocupação da medicina mental (Reis, 1994, p.22).

A consequência disso é que, para os alienistas do final do século XIX, como observa Cunha (1986, p.78), existem "muito mais loucos entre o céu e a terra do que supunha o vão senso comum". Ou como vaticina Simão Bacamarte, em tirada perfeitamente filosófica, "a loucura, objeto dos meus estudos, era uma ilha perdida no oceano da razão, começo a suspeitar que é um continente" (Assis, 1997, p.49).

Ora, é justamente nesse ponto que, na narrativa machadiana, "Itaguaí e o universo ficam à beira de uma revolução" (Assis, 1997, p.51). Com efeito, a lógica subjacente à trama da novela informava que, até então, a população da vila a partir de critérios próprios, comuns, sabia identificar os seus desatinados e com eles conviver. Doravante, após a fundação da Casa Verde, "não se sabia já quem estava são nem quem estava doido" (p.59). Apenas Simão Bacamarte, iluminado pelas revelações da ciência, era capaz de decifrar os "sinais escondidos da desordem atrás das aparências de um comportamento racional" (Castel, 1978, p.114), o 
que o permitia lançar "um olhar de suspeição sobre um vasto leque de comportamentos humanos" (Reis, 1994, p.22).

Assim é que o citado Costa, herdeiro de uma fortuna cuja renda bastava-lhe "para viver 'até o fim do mundo'”, "à vista do modo como dissipara seus cabedais” (Assis, 1997, p.51-52), já não se encontrava no perfeito equilíbrio de suas faculdades mentais; sua prima, ajuizada senhora que, ao interceder pelo parente, explicara ao alienista que a rapidez do Costa em dilapidar sua riqueza devera-se a uma praga rogada por um desafeto do tio, de quem aquele herdara a fortuna, é imediatamente considerada louca e internada na "galeria dos alucinados" (Assis, 1997, p.53); ou o caso do albardeiro que ao enriquecer resolve realizar seu sonho de construir uma bela casa, passando às manhãs nos jardim a contemplá-la e às tardes postando-se na janela com o intuito de ser admirado e respeitado. Bastou isso para o alienista diagnosticá-lo como tomado pelo "amor das pedras, mania que ele Bacamarte descobriu e estudava desde algum tempo" (Assis, 1997, p.55).

Aqui, a ironia machadiana é mordaz. Qualquer traço idiossincrático, qualquer "esquisitice" que o senso comum nomearia como ambição, orgulho, avareza, paixão desmedida, inveja, fofoca, ciúme, desgosto afetivo, mania de grandeza e até demência, merecendo da população atitudes que iam da compaixão à troça, eram (re)qualificados, (re)significados cientificamente pelo alienista numa clave necessariamente insana, e como tal não podendo permanecer à solta nas ruas. De fato, a nova teoria do psiquiatra é definidora: “A razão é o perfeito equilíbrio de todas as faculdades, fora daí insânia, insânia e só insânia" (Assis, 1997, p.50). Todavia, diante das inúmeras internações e do despotismo científico do alienista, eis que a pacata Itaguaí explode em revolta. "A Casa Verde é um cárcere privado", afirmava um "médico sem clínica" (Assis, 1997, p.55), "Bastilha da razão humana" era como a denominava o barbeiro Porfírio, líder dos agitadores, declarando perante a Câmara que Itaguaí não "podia continuar a servir de cadeia aos estudos e experiências de um déspota" (Assis, 1997, p.61).

- Devemos acabar com isto!

- Não pode continuar!

- Abaixo a tirania!

- Déspota! Violento! Golias! (p.59).

Disposto a pôr abaixo a Casa Verde, o barbeiro, cuja "alcunha familiar" de "Canjica" deu o nome à revolta, diante do crescente apoio que recebe da população e dos próprios dragões da força pública, envenena-se pelo fascínio do poder e denomina-se "protetor da vila em nome de sua majestade e do povo". Vitoriosa a rebelião, a vila respira aliviada, esperançosa e confiante de que "o alienista, dentro de vinte e quatro horas, estaria a ferros, e destruído o terrível cárcere" (Assis, 1997, p.68).

Entretanto, eis que tudo se passa diferente e agora é o próprio barbeiro, investido de suas novas funções de governo, que procura aliança com Bacamarte, reconhecendo que a questão da loucura é "puramente científica", deixando atônito o alienista:

O pasmo de Vossa Senhoria, atalhou gravemente o barbeiro, vem de não atender à grave responsabilidade do governo. O povo, tomado de uma cega piedade, que lhe dá em tal caso legítima indignação, pode exigir do governo certa ordem de atos; mas este, com a 
responsabilidade que lhe incumbe, não os deve praticar, ao menos integralmente, e tal é a nossa situação. A generosa revolução, que ontem derrubou uma câmara vilipendiada e corrupta, pediu em altos brados o arrasamento da Casa Verde; mas pode entrar no ânimo do governo eliminar a loucura? Não. E se o governo não a pode eliminar, está ao menos apto para discriminá-la, reconhecê-la? Também não; é matéria de ciência. Logo, em assunto tão melindroso, o governo não pode, não deve, não quer dispensar o concurso de vossa senhoria. O que lhe pede é que de certa maneira demos alguma satisfação ao povo. Unamo-nos e o povo saberá obedecer (Assis, 1997, p.71).

Corrompido pelo poder, Porfírio cede à ciência e à sua representação viva, Simão Bacamarte, reconhecendo que "não pode, não deve e não quer" prescindir de sua ajuda. Afinal, como ele próprio confessa, "o novo governo não tinha ainda por si a confiança dos principais da vila, mas o alienista podia fazer muito nesse ponto" (Assis, 1997, p.71). Foi o bastante para que cinco dias depois o alienista metesse na Casa Verde "cerca de cinquenta aclamadores do novo governo" (p.72). A indignação popular é imediata. Porfírio venderase ao "'ouro de Simão Bacamarte'". O barbeiro tenta reagir, mas é tarde, sendo substituído pelo seu "rival de navalha", João Pina, até que uma força mandada pelo vice-rei restabelece a ordem (p.72).

Há quem veja no episódio da "Rebelião dos Canjicas" alusões às revoltas regenciais, como a Balaiada, "que também deve seu nome à profissão humilde de um dos seus líderes" (Gledson, 1998, p.20). De fato, neste movimento, bem como na Cabanagem do Pará, o elemento popular é expressivo (negros escravos, homens livres pobres, índios aldeados e tapuias), chegando em alguns momentos a assumir uma feição bastante radical que escapa ao controle político dos grupos dominantes locais, acabando por se perder diante das rivalidade e vacilações das suas lideranças (no conto Porfírio também não contava com a confiança dos principais da vila e vacila diante dos compromissos que assumira com a população).

Conforme sugestão de John Gledson (1998, p.25), é possível que a teoria da história que embasasse os pontos de vista de Machado fosse a de Justiniano José da Rocha, expressa no seu panfleto "Ação; reação; transação", em que define a história brasileira pós-independência como "um movimento pendular entre democracia e absolutismo seguido de um período de corrupção ("transação"), representado, na sua opinião, pelo Gabinete de Conciliação de 1853-1857". Nesse caso, a "Rebelião dos Canjicas" poderia obedecer a esse mesmo movimento pendular, tudo terminando em transação, evidenciado isso na corrupção do barbeiro Porfírio, que, envenenado pelo poder, resolve trair seus comandados e negociar com Bacamarte expressão da autoridade e do poder da ciência - em defesa da ordem. Como ele mesmo diz, não se "pode atribuir ao governo intenções vandálicas", por isso ao povo deve se recomendar ordem: "A ordem, meu amigos, é a base do governo" (Assis, 1997, p.70-72).

Embora seguir por esse caminho seja tentador, retornemos ao terreno familiar da crítica específica, que emerge no conto, ao poder da medicina alienista no seu confronto com a loucura. Assim, de acordo com o narrador, após a derrota dos Canjicas, Simão Bacamarte atinge seu "grau máximo de influência" (Assis, 1997, p.73) e resolve internar meio mundo na Casa Verde:

Daí em diante foi uma coleta desenfreada. Um homem não podia dar nascença ou curso à mais simples mentira do mundo ... que não fosse logo metido na Casa Verde. 
Tudo era loucura. Os cultores de enigmas, os fabricantes de charadas, de anagramas, os maldizentes, os curiosos da vida alheia ... ninguém escapava aos emissários do alienista. Ele respeitava as namoradas e não poupava as namoradeiras, dizendo que as primeiras cediam a um impulso natural e as segundas a um vício. Se um homem era avaro ou pródigo ia do mesmo modo para a Casa Verde (Assis, 1997, p.74).

Chega mesmo a internar sua esposa, dona Evarista, acusada de "mania sumptuária": "Conto pô-la boa dentro de seis semanas" (p.75-76).

Eis que, repentinamente, após internar 4/5 da população de Itaguaí, Bacamarte assombra o vilarejo e resolve liberar todos os loucos da Casa Verde, convencido de que a correta teoria das moléstias cerebrais é precisamente a inversa da que até então acreditava: "A verdadeira doutrina deve admitir como normal e exemplar o desequilíbrio das faculdades e como hipótese patológica todos os casos em que aquele equilíbrio fosse ininterrupto". Passa a internar então aqueles em que reconhece "retidão de sentimentos, boa fé, respeito humano, generosidade" (p.76).

Novamente aqui a ironia de Machado de Assis é exemplar. Irrompe de modo estridente na superfície do texto e nas entrelinhas dá o recado sutil: a flutuação teórica espetacular e contraditória da ciência que pretende desvendar a loucura, sua facilidade em se meter pelo avesso. Onde antes havia sanidade há demência; na antiga insânia, perfeito equilíbrio. Quem pode assegurar uma verdade? Quem pode instituir os limites entre sanidade e loucura que não sejam balizados por critérios morais, políticos e preconceituosos (no sentido de pré-conceitos)? Quem pode, afinal, dizer que tal ciência é desinteressada?

É aqui que, me parece, guardadas as devidas proporções, a crítica contida em "O alienista" prenuncia, pressagia (não mais do que isso, pra não incorrer em anacronismos), a trilha analítica inaugurada por Foucault e depois seguida por outros estudiosos que interpretam o aparecimento do saber psiquiátrico desde uma perspectiva que, grosso modo, o tem visto como peça importante dos processos de controle e regulação social, portanto de poder, instituídos no contexto de aburguesamento das sociedades, além, é claro, dos próprios interesses da corporação psiquiátrica. Sendo assim, apontam as sólidas raízes políticas da psiquiatria, as intrínsecas relações entre saber, poder e normatização social, desmontando certos mitos que davam conta da sua constituição sobre o pano de fundo de um mandato exclusivamente médico-científico e crescentemente humanizador. Nessa perspectiva de análise, os manicômios, por exemplo, têm sido observados "como ... espaço[s] de poder, de elaboração de saberes relacionados com a gestão e o disciplinamento da população, e não como espaço[s] de cura do doente mental e compreensão da doença" (Campos Marín, Huerta, citados em Wadi, 2011, p.252), ou seja, como instrumentos reguladores das "tensões sociais e protetor[es] da sociedade frente às ameaças de seus membros" (Sacristan citado em Wadi, 2011, p.252).

Os estudos sobre o surgimento da psiquiatra brasileira e sobre o nascimento do hospício produzidos no Brasil, que inicialmente assumiram essa perspectiva crítica, ${ }^{9}$ como os de Machado et al. (1978), Cunha (1986), Muricy (1988), Teixeira (1998), Engel (2001), com suas importantes diferenças, ${ }^{10}$ em geral acompanharam esse viés interpretativo. Nesse caso, a influência do olhar foucaltiano sobre a questão é notável. ${ }^{11}$ Em interessante balanço historiográfico desse conjunto de trabalhos, Ribeiro (2012, p.19) salienta que o embasamento teórico deles revela 
uma certa a aproximação com as análises clássicas de cunho foucaltiano, tendendo a destacar o projeto de controle social urbano do qual a psiquiatria fizera parte. Embora Engel e Cunha apresentem uma certa ampliação crítica, principalmente embasada na história social, com maior sofisticação no trato das fontes, elas mantêm alguns pressupostos de uma determinada vertente foucaultiana, tendendo sempre a verticalizar as ações dos médicos contra a sociedade. Partindo desse aporte teórico, as análises documentais visam sempre à comprovação de tese de uma ciência que nasce para o domínio das classes mais pobres e cuja materialização é o hospício.

No entanto, estudos mais recentes têm questionado essa perspectiva interpretativa, sugerindo processos mais complexos, ao identificar embates que revelam bem mais que uma nascente psiquiatria sobremaneira voltada para o papel de agente da ordem, de controle social a serviço do poder e da dominação, portanto dedicada à "limpeza higiênica" das ruas. Buscam relativizar o poder que a medicina em geral, e não apenas a psiquiatria, exercia no século XIX, com muitas divergências e conflitos no seu interior e frente ao próprio processo de sua profissionalização e legitimação. Indicam, ademais, que não havia necessidade, nos quadros da violência aberta, sem rebuços, da ordem escravista senhorial brasileira e no período republicano imediatamente posterior, de qualquer tecnologia mais sutil, via saberes científicos, para o exercício da dominação (Patto, mar. 1996). Em resumo: consideram que os psiquiatras não teriam tido o papel que em grande medida a literatura histórica anterior, tendo em vista uma apropriação problemática do referencial foucaltiano do saber-poder, lhes vinha atribuindo, de agentes da ordem, aprioristicamente determinados a exercer um papel civilizador e higienizador. Isso por várias razões: seriam pouco importantes nesse momento, teriam reduzida força política, pelo menos bem aquém do que certos trabalhos supunham, estavam se constituindo como campo profissional, procurando legitimar-se, sobretudo os psiquiatras, muito mais envolvidos em resolver suas divergências e conflitos internos. Diante disso tudo, como poderiam exercer tão largo mandato social, servindo a propósitos estritos de controle? Consideram, pois, que o surgimento da psiquiatria e o nascimento do hospício seriam resultado de demandas de afirmação da corporação médica, mas não só como lógica de poder porquanto igualmente dedicadas às suas querelas e disputas em torno do avanço do conhecimento científico e às suas efetivas e reais possibilidades terapêuticas. Como salientam Gonçalves e Edler (2009, p.405-406), no caso do Hospício Pedro II, como a demanda era muito superior à capacidade do hospício - o que para os autores revela a importância estratégica da instituição -, havia um empenho dos médicos em dar preferência aos pacientes que "apresentassem possibilidades de cura", o que contraria as hipóteses da historiografia tradicional de que a instituição "serviria somente como um mecanismo de exclusão de elementos perturbadores". Em texto mais recente, Gonçalves (2013a, p.74-75) afirma:

Ao contrário do que vem sendo afirmado pela historiografia, havia tanto no Hospício Pedro II quanto nas casas de saúde particulares, estabelecidas na Corte imperial de 1850 a 1880, um empenho por parte dos médicos, na configuração de locais destinados à cura. A luta pela aplicação combinada de tratamento moral (preconizado por Pinel e Esquirol), como terapêutica medicamentosa (recomendada por médicos a ele contemporâneos), evidencia a atualização dos preceitos técnico-científicos acionados por médicos destes estabelecimentos que, neste contexto, não poderiam representar simples dispositivos 
de segregação de elementos da sociedade, cujos comportamentos eram considerados desviantes.

Com efeito, em relação ao surgimento do hospício, vários outros interesses (e atores) estariam envolvidos, tais como os relacionados ao ideal caritativo da Santa Casa da Misericórdia; as estratégias simbólicas ditadas pelo funcionamento de uma rede de relações e interesses (parentesco, amizade, lógica de favores) entre médicos, autoridades e figuras respeitáveis do Império; e as próprias demandas por tratamento de parte dos familiares dos potencias internos (Ribeiro, 2012; Edler, 1998; Gonçalves, Edler, 2009; Gonçalves, 2010, 2013a, 2013b).

Sem entrar propriamente no mérito da crítica produzida por essas novas interpretações, que me parecem bastante convincentes, metodologicamente sustentadas em evidências sólidas e fartas de pesquisa, a pergunta que me interessa fazer é a seguinte: se isso tudo está correto, se há de fato nas interpretações iniciais sobre o surgimento do alienismo no Brasil, um, digamos assim, excesso no poder que se atribui aos médicos/psiquiatras e ao uso instrumental do saber psiquiátrico nessa direção, além de uma perspectiva unidimensional da sua razão de ser, historicamente bem mais complexa, em que medida o teor da crítica machadiana continua procedente, assumido um "tom quase profético", no sentido de antecipar interpretações e debates que só ganhariam "fôlego um século depois" como mencionei no começo deste texto? Dito de outro modo, se as análises que ressaltam tais intenções de controle social por parte do alienismo nascente são enganosas, no sentido específico de serem marcadamente apriorísticas e unidimensionais nas suas avaliações acerca do papel dos médicos psiquiatras (e evidentemente da psiquiatria), o olhar cáustico e mordaz de Machado, acompanhando a perspectiva de leitura da sua obra como testemunho histórico (e apenas nesse sentido), também seria excessivo, distorcido, em alguma medida insuficiente, porquanto os psiquiatras estariam movidos por interesses bem mais amplos, que envolveriam, além de certas estratégias corporativas de afirmação do seu campo de conhecimento, objetivos efetivos de luta pelo avanço do conhecimento e da terapêutica voltada para a cura e o tratamento da loucura, perspectiva que o escritor teria completamente desdenhado, negligenciado, até por não acompanhar de modo mais acurado as discussões que de fato se desenvolviam no interior do campo científico da medicina mental. ${ }^{12}$

Nesse caso, o que pode ser dito é que, para além da correção maior ou menor das novas análises, não é essa exatamente a questão; o sentido da crítica machadiana, na perspectiva aqui assumida, me parece permanecer de pé, e isso pelas seguintes razões: (a) em termos do debate historiográfico, a narrativa contida em "O alienista", independente do seu estatuto de conhecimento, pode ser considerada uma importante evidência histórica de um determinado tipo de crítica que circulava no período (anos 1880, período de publicação do conto) que a fina sensibilidade de Machado era capaz de capturar, oriunda seja do senso comum ou de ambientes mais intelectualizados frequentados pelo escritor, a respeito tanto do hospício em si, nesse momento vivendo certo descrédito (problemas de superlotação, pouca capacidade de recuperação dos pacientes, favorecimentos no ingresso), como dos pressupostos teóricos da psiquiatria (fragilidade das formulações do chamado tratamento moral e avanço das concepções organicistas no âmbito da medicina geral que a psiquiatria 
encontrava dificuldade de acompanhar), só isso, a meu ver, justificando a pertinência histórica da visão cáustica do nosso autor; (b) embora o redefinam, os novos estudos não recusam a presença do mundo dos interesses envolvendo a atuação da corporação médicopsiquiátrica, portanto, suas intensas e ambicionadas relações políticas (de poder) com o contexto mais amplo da sociedade brasileira. Afinal, o que são as redes de clientelismo e a "ética de favores" (Ribeiro, 2012, p.26) vigentes no período, das quais os psiquiatras faziam parte, se não uma forma clara de exercitar e afirmar uma determinada lógica de poder, própria das sociabilidades políticas do século XIX e início do XX?; (c) se o saber/poder psiquiátrico não era tão poderoso assim, ou seja, não era capaz de cumprir funções tão largas de controle social, de limpeza e higienização das ruas, isso não me parece deslegitimar a ideia de que os psiquiatras - confiantes, ciosos e mesmo sinceramente crentes no arsenal (ou bacamarte) científico de que dispunham (ainda que tal campo científico estivesse em construção, palco de controvérsias e disputas), ambicionassem tal poder, ou pelo menos tivessem expectativas de participar desse processo, embora não como único objetivo ou objetivo primordial, como indicam acertadamente os novos trabalhos. Com efeito, é bom atentarmos para o quadro de riscos e mazelas sociais da vida brasileira que assombrava as elites na segunda metade do século XIX, tais como: o temor difuso das agitações escravas, sobretudo no Rio de Janeiro (mas não apenas), ainda que não de "consequências cataclísmicas", como salienta Chalhoub (2011), tendo em vista a sua condição de "maior cidade escravista das Américas" em meados do Oitocentos (Santos, 2013, p.184); a possível memória das revoltas regenciais de cunho popular não tão distantes, como a Balaiada e a Cabanagem, bem como a rebelião dos malês, levante de escravos islamizados que tanto assombrou a classe senhorial (lembremos a sugestão de Gledson, citada neste texto, sobre a inspiração histórica da "Rebelião dos Canjicas" no movimento dos balaios); o receio da grande presença de escravos e libertos circulando nos maiores centros urbanos, sobretudo "os maus-presságios em relação ao papel político do ex-escravo", ou seja, as dúvidas quanto a "capacidade [dos fazendeiros e elites políticas em geral] de controlar os recém-libertos, assim como os agregados", como dito por Richard Graham (1997, p.241); importante observar, nesse caso, como o decréscimo da população escrava - que passa, de acordo com Montano (2009, p.46-47), de 38\% em 1849 para 7\% em 1885, por conseguinte de aumento da população livre (com a entrada de imigrantes, a chegada de indivíduos vindos de outras regiões e o grande número de libertos e livres "não brancos") - evidenciava a necessidade de uma reestruturação nos mecanismos de controle social, notadamente no que diz respeito aos direitos políticos, "dos quais o voto pode ser tido como um bom exemplo" (Montano, 2009, p.107); o crescimento expressivo e preocupante da população do Rio de Janeiro, que passa muito rapidamente de 266.466 habitantes em 1849 para $274.972 \mathrm{em}$ 1872 e 522.651 em 1890 (quase duplicando!), com uma população não branca em torno de $45,80 \%$ em 1872 e $38,75 \%$ em 1890 , sendo por isso identificada como uma "cidade negra", "não apenas por causa do percentual de habitantes ditos de cor", mas pelo fato de eles imprimirem no espaço da cidade "uma lógica cultural que pôde assim ser denominada" (Santos, 2013, p.185-186); ${ }^{13}$ o fantasma assustador do "haitianismo" a poder se repetir no Brasil de tantos negros libertos e mesmo escravos (pelo menos até o penúltimo quartel do século XIX); a Revolta do Vintém de 1879-1880, ocorrida na Corte e que, segundo Sandra 
Graham (1991), transforma a cultura política no Brasil, que sai do âmbito circunscrito de parlamentos e gabinetes e ganha as ruas, incorporando novos atores e cenários, forçando a que, doravante, se leve em conta, nos jogos da política, as expectativas populares, para ficarmos apenas em alguns exemplos. Talvez isso explique a necessidade de reorganização e modernização da polícia ocorrida na década de 1860 (Holloway, 1997, p.194, 255) ${ }^{14}$ ou o avanço das regulamentações e posturas urbanas que procuravam intervir nas moradias populares e na cidade em geral - vide a derrubada do cortiço Cabeça de Porco em 1893, que segundo Chalhoub (1996, p.16) envolveu uma verdadeira operação de guerra - cortiços em geral considerados pelas autoridades "valhacoutos de desordeiros"; ou ainda a criação de órgãos de higiene para dar conta dos problemas sanitários, como a Junta Central de Higiene de 1855, e a afirmação da chamada "ideologia da higiene", em que "intelectuaismédicos" se incumbem de "analisa[r] a realidade, faz[er] diagnósticos, prescrev[er] cura[s] ... inabalavelmente convencidos de que só sua receita podia salvar o paciente" (p.29). Não é à toa também que no mesmo ano da abolição se discuta no Parlamento do Império uma "lei de repressão à ociosidade" e que se formule o conceito de "classes perigosas" para as populações pobres (Chalhoub, 1996, 2001); e que em 1881 se elabore uma lei de reforma eleitoral que estabelece critérios rigorosos de aferição de saber ler e escrever para a qualificação de eleitores, passando de mais de um milhão de votantes estimados em 1870 para apenas 150 mil eleitores com as novas regras estabelecidas em 1881 (Graham, 1997, p.262). Como salienta Chalhoub (2007, p.220), "numa só penada, milhares e milhares de descendentes de escravos se viram alijados da política formal nas décadas seguintes".

Há, portanto, uma nova dinâmica histórica aí que torna mais complexos a cidade e o próprio controle social, exigindo um refinamento das políticas de domínio. Nesse caso, o uso da violência sem rebuços visando manter a ordem e a paz social talvez já não desse mais conta. Observa-se, então, a necessidade de processos mais articulados e sutis para lidar com os conflitos que precisam ser enfrentados não apenas mediante a dureza da coação física, que obviamente permanece, mas também por intermédio da lei e da ciência, via negociações e barganhas, convencimentos e concessões, mas também repressões, sobretudo em cidades que crescem muito, que se avolumam e tornam mais heterogêneas suas populações e seu tecido social, como é o caso do Rio de Janeiro. A ciência médica, nesse caso, nada teria a contribuir para isso? Nem sua vertente psiquiátrica? Sendo assim, não me parece nem um pouco descabido admitir que as elites políticas brasileiras, dados seus receios não exatamente infundados, tivessem expectativas concretas e muito urgentes de "civilizar" a vida social brasileira, leia-se, manter e estabelecer novas estratégias de controle e apaziguamento social da numerosa plebe urbana e rural brasileira, as ditas "classes perigosas", para além, repito, do emprego da violência que historicamente vige no Brasil. Sendo assim, parece bastante razoável supor, acompanhando Cunha $(1990,1995)$, que o temor crescente diante das multidões nas cidades, que cresciam espantosamente e onde a pobreza e o crime se concentravam, tornasse o internamento no hospício uma solução "humanitária" e sobretudo adequada a tal situação. No caso brasileiro, por exemplo, diz a historiadora, as

multidões de pobres tinham, além do mais, um outro elemento para agravar o terror dos bem nascidos: a cor da pele e a experiência escrava, ou a estranheza de imigrantes que em muitos sentidos não falavam a mesma língua das elites locais. Este medo, aliado 
a afirmações do senso comum cientificizado - como a inferioridade racial dos negros, o 'arrivismo' aventureiro dos imigrantes ... e suas ideias exóticas, as normas de conduta para as mulheres, as regras 'normais' da sexualidade e assim por diante - tornaram o alienismo e o hospício uma receita de ampla aceitação por parte das elites (Cunha, 1995, p.52). ${ }^{15}$

Nesse caso, como o olhar tão afiado e arguto de Machado a respeito da realidade brasileira, tal como as análises de Chalhoub (2003) têm sobejamente demonstrado, deixaria de notar a inquietação latente no seio da classe dominante brasileira do período, diante desse quadro político e social ameaçador, olvidando tratar do tema?

Sendo assim, parece um caminho inegavelmente fecundo de análise (obviamente não o único), importante indício e/ou evidência histórica das discussões que circulavam no período, considerar que Machado, "criando a partir de uma experiência histórica particular" (Chalhoub, 2011, p.124), ou seja, de uma observação atenta da complexa cena política e social que se instituía no país e das prerrogativas de poder ambicionadas pelos "homens de sciência" em geral, se propusesse a empreender em "O alienista", uma poderosa e aguda crítica às pretensões do nascente alienismo brasileiro, porquanto via nele um projeto de poder algo excessivo, desmedido, autoritário, além de indiscutivelmente movido por interesses de caráter político, social e moral - ainda que Machado, um escritor, efetivamente não acompanhasse por dentro os debates e disputas vigentes no âmbito científico da psiquiatria, reproduzindo, até certo ponto, uma crítica presente no plano do senso comum mas provavelmente também em ambientes intelectualizados - tal como os estudiosos críticos do surgimento da psiquiatria aqui apresentados vinham afirmando, embora de maneira um tanto unilateral, sem introduzir maiores contradições e mediações nesse processo, como corretamente indicam os novos estudos. A questão-chave que, ao meu ver, talvez incomodasse Machado e que, portanto, merecia ou exigia a mordacidade da sua pena irônica, seria a seguinte: o que justificava o poder que a ciência psiquiátrica reivindicava para si, diante de tantas fragilidades e inconsistências teóricas, vide as recorrentes reviravoltas das teorias sobre a loucura identificadas de modo bastante irônico no conto? Como sugere acertadamente Roberto Gomes (1993, p.53), a pergunta fundamental que Machado está preocupado em colocar diante dos nossos olhos é a seguinte: "Que poder é este que emana da ciência, no que se funda, qual a razão das imunidades e privilégios que o Alienista toma para si?" Assim, para além da necessidade de apontar a existência de motivações de natureza variada no surgimento e instituição do alienismo, como indicam os novos estudos, é possível sugerir que o cenário complexo e inquietante do Rio de Janeiro da segunda metade do século XIX, a exigir novas estratégias de controle e apaziguamento social como se tentou mostrar, somado a certo descrédito notadamente no final do século nas formulações teóricas e na prática curativa da medicina mental, é que talvez tenha chamado a atenção do escritor, levando-o a tratar de maneira bastante crítica e irônica as intenções e pretensões de poder da ciência médica, notadamente a psiquiátrica, tal como é apresentada em "O alienista".

Como quer que seja, é sempre possível embaralhar um pouco os sinais da análise e considerar, acompanhando a chave de leitura que trata a obra literária como "testemunho histórico", que o fascínio narrativo e a verve encantadora e fina da crítica machadiana, denunciadora das ambições, excessos, vacilações e incoerências do saber-poder da psiquiatria 
brasileira nascente, tomada "como poderosa evidência histórica", tenham contribuído - tendo em vista a hipótese bastante factível de que essa crítica tenha exercido influência sobre alguns destes trabalhos ${ }^{16}$ - para o reforço das análises iniciais sobre o tema realizadas pelos estudiosos aqui citados, que viam no psiquiatra uma espécie de vilão a serviço da ordem e do controle social e no seu saber fundamentalmente um instrumento útil para tal intento, ou pelo menos sobrelevaram tais aspectos, em desacordo com as novas interpretações dos historiadores sobre o tema, em boa medida relativizadoras ou complexificadoras destas visões.

\section{Considerações finais}

Acompanhando a chave de leitura sugerida aqui, de observar o texto machadiano como "testemunho" de uma "experiência histórica particular", para além de outras possibilidades de interpretação que toda obra literária suscita, creio poder concluir esta breve análise reafirmando, mutatis mutandis, a proposição indicada no início do texto, de um olhar antecipador, quase profético, do escritor frente a temas candentes relacionados aos excessos e descaminhos do saber psiquiátrico, seus vínculos intrínsecos com o poder, identificados e denunciados quase um século depois por Foucault, independente da correção maior ou menor da obra foucaultiana e da própria leitura machadiana, segundo os cânones interpretativos das análises historiográficas mais atuais, e evidentemente da enorme distância de contexto histórico entre os dois momentos de análise. Com efeito, em "O alienista", Machado, num registro entre o sarcástico e o irônico, empreende uma crítica contundente às pretensões de poder que ele observa na nascente psiquiatria brasileira, suas ambições desmedidas e sua teorização claudicante, em que pese o fato de algumas das novas leituras sobre o tema matizarem, de modo geral, tal pretensão, uma vez que identificam a existência de outras motivações, envolvendo aspectos certamente bem mais plurais, portanto mais complexos e sofisticados, no surgimento e consolidação do alienismo no século XIX. Entretanto, tais críticas não me parecem desconstruir, "e nem me parece ser essa a leitura mais adequada desses novos trabalhos", as análises que denunciavam - embora de modo excessivo porquanto unilateral ou unidimensional e aí reside um dos principais problemas dos trabalhos iniciais sobre o alienismo inspirados em Foucault - as ambições extracientíficas da psiquiatria, apontando sua importante vocação social.

Sendo assim, em termos do debate histórico, concluo, pois, este breve artigo salientando a importância de reconhecer a variedade de motivações, amiúde contraditórias, presentes nos momentos iniciais (mas não apenas) de afirmação do alienismo (querelas de caráter científico, expectativas terapêuticas, disputas corporativas, interesses genuínos dos familiares, mas também a lógica de favores e os clientelismos políticos característicos do período), em conformidade com o que certos estudos recentes têm apontado com base em pesquisas metodologicamente sólidas e empiricamente documentadas, como importantes objetivos gerais de controle e poder por parte do "bacamarte" psiquiátrico, sugeridos com muita agudeza e mordacidade por Machado em "O alienista". Talvez por isso o escritor termine o conto de maneira absolutamente inusitada, transformando o alienista no único doido de Itaguaí. Com efeito, após instituir uma terapêutica que consiste em atacar cada "beleza moral ou mental ... no ponto, em que a perfeição pareça mais sólida" (Assis, 1997, p.83), consegue resultados 
fabulosos, curando todos os doentes de Itaguaí. Entretanto, Plus Ultra!: em vez de se dar por satisfeito, assola-se em dúvidas e perguntas, próprias dos grandes espíritos dedicados à ciência: "- Mas deveras estariam eles doidos e foram curados por mim, - ou o que pareceu cura não foi mais do que o perfeito desequilíbrio do cérebro?" (Assis, 1997, p.85).

O resultado a que chega é surpreendente. Itaguaí "não possuía um só mentecapto", exceto ele próprio, porquanto lhe pareceu ser o único que "possuía a sagacidade, a paciência, a perseverança, a tolerância, a veracidade, o vigor moral, a lealdade, todas as qualidades enfim que podem formar um acabado mentecapto" (p.85).

Suprassumo da ironia machadiana: no ponto de partida Bacamarte funda a Casa Verde com o objetivo principal de instituir um lugar indispensável para o estudo científico da loucura, onde se tornasse possível a descoberta da "causa do fenômeno e o remédio universal" (p.42). Em outras palavras: espaço imprescindível de reunião da teoria e da prática. No ponto de chegada, entretanto, a Casa Verde se torna até dispensável. O "cavaleiro andante da ciência" (Gomes, 1993, p.145) ele próprio passa a reunir em si a teoria e a prática realizando, anota Gomes (p.151), o "ideal científico" positivista de "unificação entre sujeito e objeto".

\section{NOTAS}

${ }^{1}$ História da loucura na Idade Clássica foi originariamente o trabalho com que Foucault fez jus ao seu doctorat d'État (habilitação que permite postular o cargo de professor universitário), sendo publicado em primeira edição na França em 1961. No Brasil foi publicado pela editora Perspectiva em 1978.

${ }^{2}$ Ver, a esse respeito, Engel (2001).

${ }^{3}$ Conforme mostra Cunha (1990, p.13-14), em boa medida aqueles que serão depois vistos como loucos perigosos, no século XIX muitas vezes eram identificados a tipos pitorescos de rua, "aceitos com tolerância, protegidos espontaneamente ... objeto às vezes de forte apreço popular, motivo de riso frequentemente, mas não necessariamente de medo e inquietação".

${ }^{4}$ Esse período pode ser identificado pelas referências à queda da Bastilha e à presença do vice-reinado no Brasil. Claro que nesse tempo ainda não estava colocada a questão da loucura nos termos em que se apresenta no século XIX, tratando-se isso possivelmente de um ardil machadiano para, como sugere Katia Muricy (1988, p.33), "sentir-se mais à vontade na crítica às concepções científicas suas contemporâneas".

${ }^{5}$ Um dos objetivos iniciais da medicina alienista era "medicalizar" o asilo e, consequentemente, a loucura, condição de possibilidade para sua afirmação como saber autônomo. Ver Machado et al. $(1978$, p.453) e Cunha (1986, p.41).

${ }^{6}$ Trabalhos recentes têm relativizado o embate entre a Santa Casa e os médicos, observando aspectos terapêuticos desde o tempo em que a instituição esteve sob controle religioso, e não apenas com a chegada da República, quando então os médicos assumiriam o controle do hospício e se instalaria um processo efetivo de "medicalização da loucura" (Gonçalves, Edler, 2009; Gonçalves, 2013a).

${ }^{7} \mathrm{Na}$ verdade, a perspectiva de confinamento da loucura no hospício para servir como laboratório de observação e produção de um saber, e também de uma possível cura, se associava crescentemente à construção de uma imagem de periculosidade para ela, particularmente acentuada no contexto de explosão urbana relacionada à afirmação da ordem burguesa no país, trazendo à tona todo um quadro de mudanças frenéticas e inquietantes (Cunha, 1986, 1990).

${ }^{8}$ Esse personagem é citado por Machado de Assis na página 59.

${ }^{9}$ Refiro-me aqui aos trabalhos produzidos por estudiosos, não somente historiadores profissionais, que se debruçaram sobre o tema apoiados, como indicam Venâncio e Cassilia (2010, p.24), em um "novo fazer historiográfico tanto do ponto de vista da filiação teórica ... quanto do ponto de vista da eleição de novos tipos de fontes primárias". Sendo assim, resultam críticos da primeira leva de estudos “'clássicos' ou 'pioneiros' elaborados principalmente durante o século XIX e primeira metade do século XX", que assumiam uma perspectiva memorizadora, evolucionista e canônica de modo a celebrar a "evolução das ciências médicas", 
em geral produzidos por "psiquiatras de renome" (p.26). Em termos cronológicos, os trabalhos críticos a essa primeira leva de estudos "pioneiros" ou "clássicos" datam de finais dos anos 1970 em diante. Para um interessante balanço do percurso dos estudos sobre a história da psiquiatria no Brasil, ver Venâncio, Cassilia (2010). Para um quadro mais geral das "trilhas da história da loucura e da psiquiatria", ver Wadi (2011, p.250-254).

${ }^{10}$ Considero, por exemplo, que os trabalhos de Cunha e Engel apresentam diferenças importantes, a começar pelo fato de incorporar Foucault mas não assumir exatamente uma perspectiva que poderíamos chamar de "foulcaltiana", aproximando-se bem mais da história social inglesa. Cunha, aliás, tem-se apresentado em muitos textos como uma das mais ásperas críticas do que o historiador Robert Darnton chamou ironicamente de "foucaltianismo pop" (citado em Cunha, 1995, p.43), considerando que a "inflexão nitidamente foucaltiana" de certas interpretações concebe os saberes como uma forma de domínio e poder "disseminado por todos os poros da sociedade, sem um lugar preciso de emanação, marcado pelo peso da verdade e da persuasão", o que gera uma "história descarnada, na qual os conflitos não têm espaço para manifestar-se, subsumidos pela onipresença surda dos saberes, da disciplina, da norma ou dos dispositivos de poder" (Cunha, 2003, p.121) O trabalho de Engel (2001) resultou de uma tese de doutorado defendida em 1995 no programa de história social da Universidade Estadual de Campinas.

${ }^{11}$ Estudos recentes, como o de Lima (2011, p.150-151), por exemplo, ainda corroboram as afirmações de que a psiquiatria do século XIX "apenas retirava os doentes das ruas e do convívio social" semelhante ao modo como se procedia em relação "aos mendigos, aos moradores de rua, aos ladrões e criminosos que aos olhos dos administradores públicos precisavam ser tirados da sociedade". Sendo assim, considera que o tratamento dos alienados estava "longe de ser [movido por] uma atitude humanitária". Embora não indique suas fontes, o que me parece um problema grave, esse autor apresenta um relato do papel dos médicos e da situação dos hospícios, que vale descrever pela contundência e total adesão às teses do saber/ poder psiquiátrico e do controle social: "Nos hospícios os médicos representavam instrumentos de poder responsáveis pela rejeição e discriminação dos loucos. Eram os médicos quem classificavam os loucos como terríveis e traiçoeiros, mansos, perigosos... Na maioria dos casos a classificação tinha estreita relação com a condição social do doente. A vida nos hospícios era tão caótica que os moradores das cidades, onde eles se situavam, evitavam passar pelas suas proximidades para não ver ou ouvir o clamor de seus moradores que presos à grade de ferro, gritavam e gesticulavam clamando em agonia por socorro". Oda e Dalgalarrondo (2005, p.1005) sugerem algo semelhante - embora com base nas suas fontes - quando afirmam, por meio da análise de trechos selecionados de 49 relatórios de presidentes de cinco províncias do Brasil entre 1846 e 1889, que havia uma clara "contradição entre o discurso que enunciava um projeto de assistência oficial e moderno aos loucos e a prática realmente efetivada com relação aos internos", tratando-se de "pessoas pobres submetidas a reclusão forçada e péssimas condições de vida, durante toda a segunda metade do século XIX", situação "que partilhavam com outros doentes sem posses".

${ }^{12}$ Interessante notar como muitos médicos e psiquiatras que se debruçaram sobre a obra do escritor viram em muitos dos seus personagens e no modo como ele tratava a questão da loucura ecos da "personalidade mental de Machado", com referências negativas a sua condição mestiça e a sua gagueira, sua "vergonha de origem", "complexo de inferioridade", "temperamento mórbido", "constituição patológica", em suma, um verdadeiro "caso clínico". Como indica Lima (2009, p.651), para alguns desses médicos - em verdade três autores por ela analisados - a "obsessão de Machado pelo problema da loucura e pela anormalidade seria prova da proximidade que com elas mantinha". Curioso é que em geral esses médicos manifestavam "admiração pelo escritor", não pretendendo pôr "em questão seu valor" (p.651). Sobre esse tema, vale consultar integralmente o interessantíssimo artigo de Lima (2009).

${ }^{13}$ Montano (2009, p.46-47) apresenta outros números, mas que apenas reafirmam o crescimento expressivo da população: 205.906 habitantes em 1849 para 235.381 em 1870 e 522.651 em 1890 (aumento de aproximadamente $122 \%$ neste último período). Para um exaustivo tratamento demográfico da realidade econômica e das condições gerais de vida na "multifacetada" cidade do Rio de Janeiro entre as décadas de 1870 e 1880, consultar Montano (2009, p.41-94).

${ }^{14}$ Como assinala Holloway (1997, p.251), no seu rigoroso estudo sobre a instituição policial no Rio de Janeiro, à medida "que a sociedade foi se tornando mais complexa, fluida e impessoal, novas técnicas se fizeram necessárias para suplementar o controle dos senhores sobre os escravos e para estender esse controle às crescentes camadas sociais inferiores livres. O novo Estado tratou de suprir essa necessidade, e o sistema policial herdado do final do período colonial evolui para reprimir e excluir aquele segmento da população urbana que pouco ou nada recebia dos benefícios que o liberalismo garantia para a minoria governante. O sistema de controle construído e modernizado para fazer frente a virtuais rebeliões políticas ou de escravos urbanos foi mantido e ampliado, ainda que a razão original de sua existência tenha ficado grandemente 
comprometida com a consolidação política e o lento declínio da escravidão. Assim o sistema passou a cumprir novas funções num contexto socioeconômico cambiante".

15 Segundo Cunha (1995, p.52), mesmo as classes populares podem ter, em dado momento, passado a aceitar as normas do saber alienista porquanto "as condições de vida na cidade industrial tornavam difícil a convivência com pessoas 'diferentes' e a presença crescente da polícia transformava sua permanência fora dos muros e da proteção médica um exercício perigoso de sobrevivência”. Isso, de certa forma, corrobora interpretações mais recentes, como a de Ribeiro (2012), que salienta o próprio interesse das famílias dos potenciais internos na criação e consolidação do Hospício Pedro II no Rio de Janeiro. Sobre a representação das cidades como lugares de ameaça e perigo, ver Bresciani (1985).

${ }^{16}$ Kátia Muricy (1988), no seu já citado A razão cética, explicitamente se propõe a analisar o papel normalizador da medicina por meio da obra literária de Machado. Aliás, essa filósofa é uma das autoras do trabalho coletivo Danação da norma (Machado et al., 1978), geralmente apresentado como o que inaugurou a perspectiva crítica acerca do poder médico inspirada em Foucault.

\section{REFERÊNCIAS}

ASSIS, Joaquim Maria Machado de. Contos escolhidos. São Paulo: O Globo; Klick Editora. 1997.

BRESCIANI, Maria Stella Martins.

Metrópoles: as faces do monstro urbano (as cidades no século XIX). Revista Brasileira de História, v.5, n.8-9, p.35-68. 1985.

CASTEL, Roberto.

A ordem psiquiátrica: a idade de ouro do alienista. Rio de Janeiro: Graal. 1978.

CHALHOUB, Sidney.

Visões da liberdade: uma história das últimas décadas de escravidão na Corte. São Paulo: Companhia das Letras. 2011.

CHALHOUB, Sidney.

Solidariedade e liberdade: sociedades beneficentes de negros e negras no Rio de Janeiro na segunda metade do século XIX. In: Cunha, Olívia Maria Gomes da; Gomes, Flávio dos Santos (Org.). Quase-cidadão: histórias e antropologias da pósemancipação no Brasil. Rio de Janeiro: Editora FGV. 2007.

CHALHOUB, Sidney.

Machado de Assis historiador. São Paulo:

Companhia das Letras. 2003.

CHALHOUB, Sidney.

Trabalho, lar e botequim: o cotidiano dos trabalhadores da Belle Époque. Campinas: Editora da Unicamp. 2001.

CHALHOUB, Sidney.

Cidade febril: cortiço e epidemias na Corte imperial. São Paulo: Companhia das Letras. 1996.

CHALHOUB, Sidney; PEREIRA, Leonardo Afonso de M. (Org.).

A história contada: capítulos de história social da literatura no Brasil. Rio de Janeiro: Nova Fronteira. 1998.
CUNHA, Maria Clementina Pereira.

Os bacamartes da República: saberes e poderes no Brasil da virada do século. In: Silva, Fernando Teixeira da et al. (Org.). República, liberalismo e cidadania. Piracicaba: Unimep. 2003.

CUNHA, Maria Clementina Pereira.

Persuasão e violência: o alienismo e suas "artes de curar". In: Mariguela, Márcio (Org.). Foucault e a destruição das evidências. Piracicaba: Unimep. 1995.

CUNHA, Maria Clementina Pereira.

Cidadelas da ordem: a doença mental na República. São Paulo: Brasiliense. 1990.

CUNHA, Maria Clementina Pereira.

O espelho do mundo: Juquery, a história de um asilo. Rio de Janeiro: Paz e Terra. 1986.

EDLER, Flávio C.

A medicina brasileira no século XIX: um balanço historiográfico. Asclépio, v.2, n.1, p.169-186. 1998.

ENGEL, Magali Gouveia.

Os delírios da razão: médicos, loucos e hospícios (Rio de Janeiro, 1830-1930). Rio de Janeiro: Editora da Fiocruz. 2001.

GLEDSON, John.

A história do Brasil em "Papéis avulsos" de Machado de Assis. In: Chalhoub, Sidney; Pereira, Leonardo Afonso de M. (Org.). A história contada: capítulos de história social da literatura no Brasil. Rio de Janeiro: Nova Fronteira. 1998.

GOMES, Roberto.

O alienista: loucura, poder e ciência. Tempo Social, v.5, n.1-2, p.145-160. 1993.

GONÇALVES, Monique de $\mathrm{S}$.

Os primórdios da psiquiatria no Brasil: o Hospício Pedro II, as casas de saúde particulares e seus pressupostos metodológicos (1850-1880). 
Revista Brasileira de História das Ciências, v.6, n.1, p.60-77. 2013a.

GONÇALVES, Monique de S.

A imprensa médica na Corte imperial: a loucura e as doenças nervosas nas páginas dos periódicos especializados (1850-1880). Varia História, v.29, n.49, p.143-168. 2013b.

GONÇALVES, Monique de S.

Mente sã, corpo são: disputas, debates e discursos médicos na busca pela cura das "nevroses" e da loucura na Corte imperial (1850-80). Tese (Doutorado em História das Ciências e da Saúde) - Casa de Oswaldo Cruz, Fiocruz, Rio de Janeiro. 2010.

GONÇALVES, Monique de S.; EDLER, Flávio C. Os caminhos da loucura na Corte imperial: um embate historiográfico acerca do funcionamento do Hospício Pedro II de 1850 a 1889. Revista Latino-americana de Psicopatologia Fundamental, v.12, n.2, p.393-410. 2009.

GRAHAM, Richard.

Clientelismo e política no Brasil do século XIX. Rio de Janeiro: Editora da UFRJ. 1997.

\section{GRAHAM, Sandra.}

O motim do vintém e a cultura política no Rio de Janeiro 1880. Revista Brasileira de História, v.10, n.20, p.211-232. 1991.

HOLLOWAY, Thomas H.

Polícia no Rio de Janeiro: repressão e resistência numa cidade do século XIX. Rio de Janeiro: Editora FGV. 1997.

LIMA, Elisabeth Maria Freire de Araújo. Machado de Assis e a psiquiatria: um capítulo das relações entre arte e clínica no Brasil. História, Ciências, Saúde - Manguinhos, v.16, n.3, p.641654. 2009.

LIMA, Márcio José Silva.

História da loucura na obra "O alienista" de Machado de Assis: discurso, identidades e exclusão no século XIX. Caos, n.18, p.141-153. 2011.

MACHADO, Roberto et al.

Danação da norma: medicina social e constituição da psiquiatria no Brasil. Rio de Janeiro: Graal. 1978.

MONTANO, Leandro Duarte.

Para além de um vintém: diálogos políticos $\mathrm{e}$ ação popular na Corte imperial (1870-1880). Dissertação (Mestrado em História Social) - Instituto de Filosofia e Ciências Sociais, Universidade Federal do Rio de Janeiro, Rio de Janeiro. 2009.
MURICY, Kátia.

A razão cética: Machado de Assis e as questões de seu tempo. São Paulo: Companhia das Letras. 1988.

ODA, Ana Maria G. Raimundo;

DALGALARRONDO, Paulo.

História das primeiras instituições para alienados no Brasil. História, Ciências, Saúde -

Manguinhos, v.12, n.3, p.983-1010. 2005.

PATTO, Maria Helena Souza.

Teoremas e cataplasmas no Brasil monárquico: o caso da medicina mental. Novos Estudos Cebrap, n.44, p.180-199. mar. 1996.

PESSOTI, Isaias.

O século dos manicômios. Rio de Janeiro: 34 Letras. 1986.

REIS, José Roberto Franco Reis.

Higiene mental e eugenia: o programa de regeneração nacional da Liga Brasileira de Higiene Mental (1920-40). Dissertação (Mestrado em História Social) - Instituto de Filosofia e Ciências Humanas, Universidade Estadual de Campinas, Campinas. 1994.

RIBEIRO, Danielle Corrêa.

O Hospício de Pedro II e seus internos no ocaso do Império: desvendando novos significados. Dissertação (Mestrado em História das Ciências e da Saúde) - Casa de Oswaldo Cruz, Fiocruz, Rio de Janeiro. 2012.

SANTOS, Lucimar Felisberto dos.

Moradas, ocupação e territórios urbanos: crioulos e africanos no rio de Janeiro, 1870-1910. In:

Sanglard, Gisele; Araújo, Carlos Eduardo Moreira; Siqueira, José Jorge (Org.). História urbana: memória, cultura e sociedade. Rio de Janeiro: Editora FGV. 2013.

TEIXEIRA, Manoel Olavo Loureiro.

Deus e a ciência na terra do sol: o Hospício de Pedro II e a constituição da medicina mental no Brasil. Tese (Doutorado em Psiquiatria e Saúde Mental) - Instituto de Psiquiatria, Universidade Federal do Rio de Janeiro, Rio de Janeiro. 1998.

VENÂNCIO, Ana Teresa; CASSILIA, Janis

Alessandra.

A doença mental como tema: uma análise dos estudos no Brasil. Espaço Plural, ano 11, n.22, 2010.

WADI, Yonissa M.

"Entre muros": os loucos contam o hospício.

Topoi, v.12, n.22, p.250-269. 2011. 